\title{
Optimization of Somatic Embryogenesis Protocol for Locally Adapted Eggplant (Solanum melongena L.) Varieties in Bangladesh
}

\author{
M. Ashraful Habib ${ }^{1 *}$, M. Abdul Muktadir ${ }^{2}$, M. Rezwan Kabir, M. \\ A. Khaleque Mian ${ }^{3}$ and M. A. Yousuf Akhond \\ Biotechnology Division, Bangladesh Agricultural Research Institute, Gazipur-1701, \\ Bangladesh
}

Key words: Optimization, Somatic embryogenesis, Solanum melongena

\begin{abstract}
Five eggplant cultivars were cultured on MS supplemented with $0.5 \mathrm{mg} / 1$ 2,4-D, resulting in the development of embryogenic calli. When the calli were subcultured onto growth regulator free MS, BARI Begun-4 produced the highest number of embryos (64) per explant followed by BARI Begun-1 (57). Later both the superior varieties in terms of embryo production were cultured on MS having 0.5, 1.0, 1.5 and $2.0 \mathrm{mg} / \mathrm{l}$ 2,4-D along with a control. BARI Begun-4 produced the highest number of embryos (67) on MS supplemented with 1.0 mg/l 2,4-D which was closely followed by BARI Begun-1 (62). Regenerated plantlets were successfully established in soil following acclimation.
\end{abstract}

\section{Introduction}

Eggplant alternatively known as brinjal (Solanum melongena L.) belongs to Solanaceae and is one of the most popular vegetable crops in Bangladesh. It is the second most important vegetable in terms of consumer preference and production in Bangladesh (BBS 2014). The crop is native to Indian subcontinent therefore, a wide range of genetic diversity being present in the cultivated as well as among wild species. Cultivated eggplants are susceptible to wide range of biotic as well as abiotic stresses. In contrast the majority of the wild relatives are nearly resistant to all known pests and pathogens and hence, an important

*Author for correspondence: <ashhabib02@yahoo.com>. ${ }^{1}$ Agriculture Research \& Development, International Rice Research Institute, Bangladesh. ${ }^{2}$ Grain Legume Breeding, Faculty of Agriculture and Environment, The University of Sydney, Centre for Carbon Water and Food (CCWF), 380 Werombi Road, Camden, Brownlow Hill, NSW 2570, Australia. ${ }^{3}$ Department of Genetics and Plant Breeding, Bangabandhu Sheikh Mujibur Rahman Agricultural University, Gazipur-1706. Bangladesh. 
source for improvement of this crop. Due to sexual incompatibilities (Collonier et al. 2001) these traits have not been utilized effectively. However, various tissue culture based approaches, such as somaclonal variation, somatic hybridization, somatic embryogenesis and genetic transformation have been investigated in this crop and found to be promising.

Somatic embryogenesis has been recognized as the efficient method for in vitro mass propagation of plants (Parrot et al. 1991, Durzan and Durzan 1991). The main advantage of somatic embryogenesis over axillary or adventitious shoot propagation is the possibility of potentially unlimited production of single individuals with functional shoot and root. Somatic embryogenesis in eggplant has been reported from stems, hypocotyls, leaves, cell suspension, isolated protoplasts and roots (Matsuoka and Hinata 1979, Gleddie et al. 1983, Sharma and Rajam 1995a, Yadav and Rajam 1997). Development of an efficient embryogenesis protocol could pave the way for development of pest resistance and stress tolerant varieties of this crop through the application of modern biotechnological methods.

\section{Materials and Methods}

Seeds of four eggplant varieties BARI Begun-1, BARI Begun-4, BARI Begun-5, BARI Begun-6 and an elite local cultivar Islampuri were collected from the Horticulture Research Center, Bangladesh Agricultural Research Institute, Gazipur-1701. Seeds were first dipped into 100\% ethanol for 20 - 30 seconds followed by 4 washings with sterile distilled water. After that Tween 20 (3 - 5 drops) were added in $100 \mathrm{ml} \mathrm{2 \%}$ sodium hypochlorite solution (40\% Clorox). Seeds were dipped in a $50 \mathrm{ml}$ conical flask containing the prepared solution for 20 minutes with frequent shaking followed by 4 washings with sterile distilled water. Finally, 25 - 30 seeds were inoculated in each small jar containing $30 \mathrm{ml}$ agar solidified half strength of MS with $3 \%$ sucrose for supporting seedling development and kept in dark for $8-10$ days at $25^{\circ} \mathrm{C}$ and $60-70 \%$ relative humidity.

Hypocotyl segments of 8 - 10 day old in vitro grown seedlings of aforementioned eggplant cultivars were used as explants. About $5 \mathrm{~mm}$ long segments taken from the apical portion of the hypocotyl were inoculated on culture media (Muktadir 2008) prepared as per treatment combinations. Culture conditions were maintained by keeping the cultures in dark for five weeks then transferred to light (Akhond and Bhuiyan 2001). Temperature was set at $25^{\circ} \mathrm{C}$ with a light illumination of 2000-3000 lux from fluorescent lamps maintained under the photoperiod of $(16 \mathrm{~L} / 8 \mathrm{D})$ and at $60-70 \%$ relative humidity. 
Initially the cultivars were evaluated for embryogenic response on medium supplemented with $0.5 \mathrm{mg} / 1$ 2,4-D. Three replicates and 12 explants per replicate had been used. Fifty embryos per replicate were used for embryo germination and plantlet development. Later, two best performing varieties were tested against four different concentrations $(0.5,1.0,1.5$ and $2.0 \mathrm{mg} / \mathrm{l})$ of 2,4-D along with a control following the same methodology mentioned previously.

The experiment was laid out in single factor CRD with three replications and results were analyzed by using MSTAT-C program. Differences among the means were compared following DMRT test at $5 \%$ level of significance.

\section{Results and Discussion}

Callus initiation was observed within 14 - 20 days of culture in all the cultivars. When the calli were transferred to regeneration medium (MS), a mass of somatic embryos were observed approximately after 45 days (Fig. 1C, D). Maximum number of embryos were observed after 6 weeks of culture and the development continued up to about 6 weeks. Fifty embryos from each cultivar were cultured for germination in growth regulator-free MS. Callus formation, somatic embryo development and in vitro embryo germination showed significant differences. BARI Begun-4 and BARI Begun-1 showed better performance in all four parameters while the local cultivar Islampuri found to be the least responsive among the cultivars (Table 1).

Table 1. Embryogenic response of five eggplant cultivars to $0.5 \mathrm{mg} / 1$ 2,4-D (mean values).

\begin{tabular}{ccccc}
\hline Cultivars & $\begin{array}{c}\text { Explant } \\
\text { producing } \\
\text { callus (\%) }\end{array}$ & $\begin{array}{c}\text { Explant } \\
\text { producing } \\
\text { embryo (\%) }\end{array}$ & $\begin{array}{c}\text { Embryos per } \\
\text { explants } \\
(\text { no. })\end{array}$ & $\begin{array}{c}\text { In vitro embryo } \\
\text { germination } \\
(\%)\end{array}$ \\
\hline BARI Begun-1 & $94 \mathrm{a}$ & $83 \mathrm{a}$ & $57 \mathrm{~b}$ & $82 \mathrm{~b}$ \\
BARI Begun-4 & $97 \mathrm{a}$ & $86 \mathrm{a}$ & $64 \mathrm{a}$ & $88 \mathrm{a}$ \\
BARI Begun-5 & $81 \mathrm{~b}$ & $72 \mathrm{~b}$ & $49 \mathrm{c}$ & $78 \mathrm{c}$ \\
BARI Begun-6 & $69 \mathrm{c}$ & $63 \mathrm{c}$ & $42 \mathrm{~d}$ & $80 \mathrm{~b}$ \\
Islampuri & $61 \mathrm{~d}$ & $53 \mathrm{~d}$ & $39 \mathrm{~d}$ & $80 \mathrm{~b}$ \\
\hline
\end{tabular}

Means followed by different letters within a column are significantly different at $\mathrm{p}<0.05$ (Duncan 1955).

Genotype was found to be the most important factor affecting somatic embryogenesis and organogenesis (Sharma and Rajam 1995a,b, Anisuzzaman et al. 1993). A few authors have also concluded that success of in vitro morphogenesis in eggplant largely depends on factors like donor plant 
characteristics, composition of culture medium and control of the physical environment (Ali et al. 1991, Akhond and Bhuiyan 2001, Muktadir 2008). Systematic screening of one or more of these factors with the plant of interest has been the most common experimental approach for achieving regeneration in vitro. On the basis of initial results, two responsive varieties i.e. BARI Begun-1 and BARI Begun-4 were tested against four different levels of 2,4-D along with a control treatment under in vitro conditions.

Table 2. Embryogenic response of BARI Begun-1 and BARI Begun-4 to different concentrations of 2,4-D (mean values).

\begin{tabular}{|c|c|c|c|c|c|c|c|c|c|c|}
\hline \multirow[t]{2}{*}{ Treatment } & \multicolumn{2}{|c|}{$\begin{array}{l}\text { Explant } \\
\text { producing } \\
\text { callus (\%) }\end{array}$} & \multicolumn{2}{|c|}{$\begin{array}{c}\text { Explant } \\
\text { producing } \\
\text { embryos }(\%)\end{array}$} & \multicolumn{2}{|c|}{$\begin{array}{l}\text { Embryos/ } \\
\text { explant } \\
\text { (no.) }\end{array}$} & \multicolumn{2}{|c|}{$\begin{array}{c}\text { In vitro } \\
\text { embryo } \\
\text { germination }(\%)\end{array}$} & \multicolumn{2}{|c|}{$\begin{array}{c}\text { Ex vitro } \\
\text { establishment } \\
(\%)\end{array}$} \\
\hline & A & B & A & B & A & B & A & B & $\mathrm{A}$ & B \\
\hline T0 & $0 \mathrm{~b}$ & $\mathrm{Ob}$ & $0 \mathrm{e}$ & $0 \mathrm{e}$ & $0 \mathrm{e}$ & $0 \mathrm{e}$ & $0 \mathrm{~d}$ & $0 \mathrm{~d}$ & $0 \mathrm{~d}$ & $0 \mathrm{~d}$ \\
\hline $\mathrm{T} 1$ & $94 a$ & $97 a$ & $83 b$ & $86 a b$ & $57 b$ & $64 a$ & $82 b$ & $88 a$ & $90 a$ & $94 a$ \\
\hline $\mathrm{T} 2$ & $94 a$ & $97 a$ & $89 a$ & $94 a$ & $62 \mathrm{ab}$ & $67 a$ & $72 c$ & $80 \mathrm{~b}$ & $84 b$ & $90 a$ \\
\hline T3 & $100 a$ & $100 a$ & $72 c$ & $81 b$ & $43 \mathrm{~cd}$ & $48 \mathrm{c}$ & $72 c$ & $82 b$ & $78 \mathrm{bc}$ & $80 \mathrm{~b}$ \\
\hline $\mathrm{T} 4$ & $100 a$ & $100 a$ & $58 d$ & $50 \mathrm{~d}$ & $35 d$ & $38 d$ & $70 \mathrm{c}$ & $84 \mathrm{ab}$ & $68 c$ & $72 c$ \\
\hline
\end{tabular}

Means followed by different letters within a column are significantly different at $p<0.05$ (Duncan 1955). To - $0.0 \mathrm{mg} / \mathrm{l} \mathrm{2,} \mathrm{4-D} \mathrm{(Control),} \mathrm{T}_{1}-0.5 \mathrm{mg} / \mathrm{l}$ 2, 4-D, $\mathrm{T}_{2}-1.0 \mathrm{mg} / \mathrm{l} 2,4-\mathrm{D}, \mathrm{T}_{3}-$ $1.5 \mathrm{mg} / 1$ 2, 4-D, T4 - 2.0 mg/1 2, 4-D. A - BARI Begun-1, B- BARI Begun-4.

All the related characters studied showed significant differences in response to different concentrations of 2,4-D (Table 2). Callus induction was noticed after more or less the same interval for all the treatments i.e. within 2 - 3 weeks of culture initiation (Fig. 1A, B). The highest percentage (100) of callus formation was observed in 1.5 and $2.0 \mathrm{mg} / \mathrm{l}$ 2,4-D in BARI Begun-4 and BARI Begun-1, respectively, which has no significant difference with other treatments (Table 2). Callus induction remained the same in other treatments while concentration of 2,4-D was increased. It was observed that the embryogenic masses derived from higher concentrations of the growth regulator treatments had lower propensity for producing embryos. In the control treatment, no callus was produced but direct shoot development was observed. Experimental results from Akhond and Bhuiyan (2001) also support this observation. The highest number of embryos per explant (67 and 62) was recorded in $1.0 \mathrm{mg} / \mathrm{l}$ 2,4-D for BARI Begun-4 and BARI Begun-1, respectively which was statistically superior to the rest of the treatments (Table 2). With the further increase of concentrations of growth regulator, number of embryos per explant was less. Akhond and Bhuiyan (2001) and Ali et al. (1991) also obtained better result in lower concentration though 0.5 
$\mathrm{mg} / 1$ 2,4-D was found suitable in both the studies. Ali et al. (1991) obtained 53 embryos/explant from the cultivar Hathazari on half strength MS + $1.0 \mathrm{mg} / 1$ 2,4-D using apical hypocotyl.
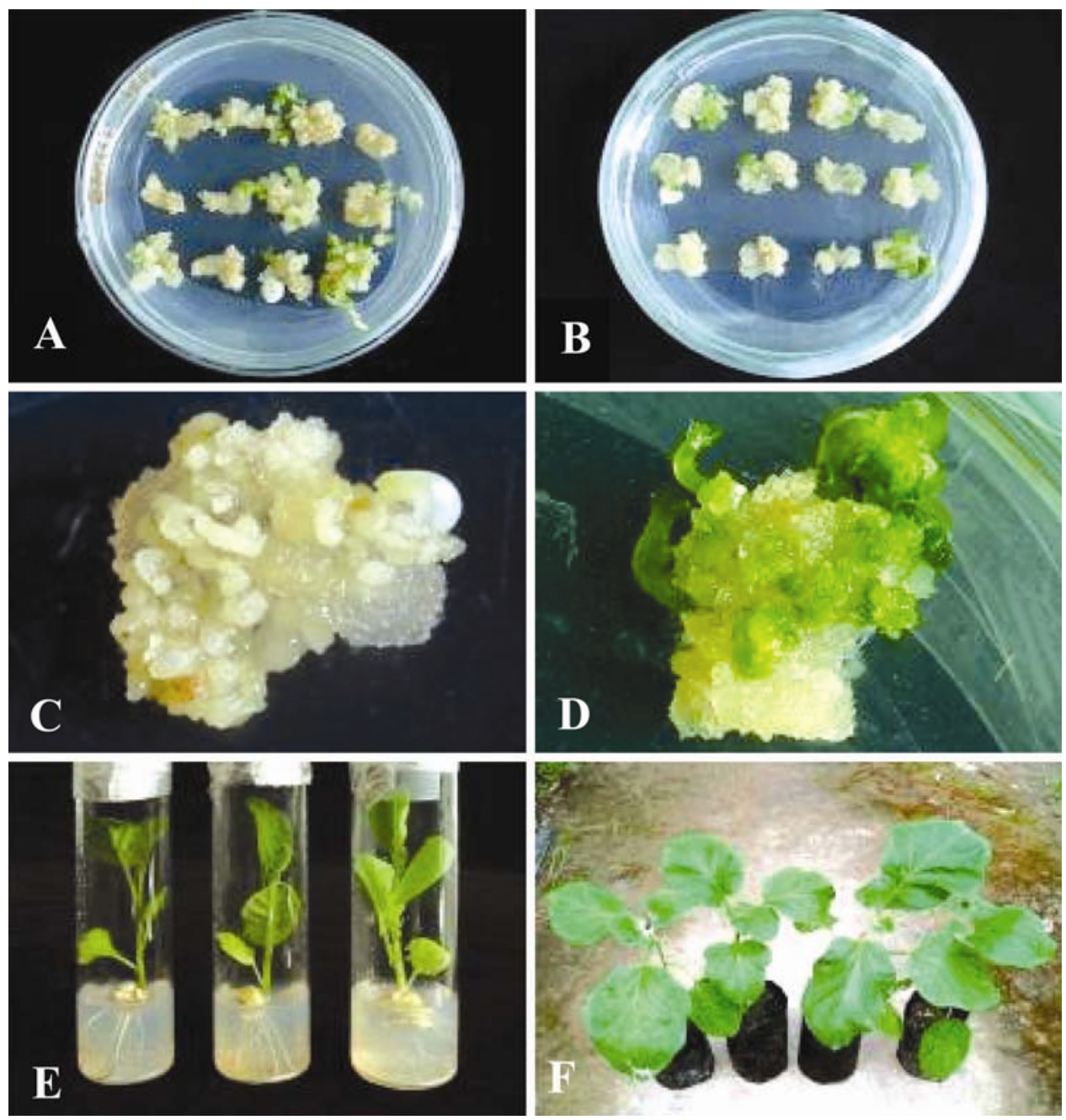

Fig. 1. A. Embryogenic calli of BARI Begun-1. B. Embryogenic calli of BARI Begun-4. C.

Close view of embryogenic callus showing differentiated embryos. D. Embryogenic callus with germinating embryos. E. Plantlet with well-developed root system. F. Successful establishment of plants in soil.

Percentage of in vitro embryo germination derived from different treatments also showed significant differences. Germination was maximum from $1.0 \mathrm{mg} / \mathrm{l}$ 2,4-D derived embryos for both the varieties which indicated statistical superiority to rest of the treatments (Table 2). In vitro germinated embryos were 
successfully transferred to soil in pots following acclimated. Ex vitro establishment was the best in plantlets derived from $0.5 \mathrm{mg} / 12,4-\mathrm{D}$ treatment and had no statistical difference with $1.0 \mathrm{mg} / 1$ 2,4-D derived plantlets. The interaction of genotype and growth regulators in regeneration either organogenesis or somatic embryogenesis is a common phenomenon (Sharma and Rajam 1995, Hansen et al. 1999, Chen and Dribnenki 2002, Kantharajah and Golegaonkar 2004) and in the present work this influence was clearly manifested in different phases of regeneration.

\section{References}

Akhond MAY and Bhuiyan MSA (2001) Regeneration of eggplant (Solanum melongena L.) through somatic embryogenesis. Plant Tissue Cult. 11(1): 11-14.

Ali M, Okubo H and Fujieda K (1991) In vitro multiplication of intra- and interspecific Solanum hybrids through somatic embryogenesis and adventitious organogenesis. J. Jpn. Soc. Hortic. Sci. 60(3): 601-612.

Anisuzzaman M, Kamai AHM, Islam R, Hossain M and Joarder OI (1993) Genotypic differences in somatic embryogenesis from hypocotyl explants in Solanum melongena L. Plant Tissue Cult. 3(1): 35-40.

BBS (2014) Statistical Yearbook Bangladesh. 34 th edition. Bangladesh Bureau of Statistics. Ministry of Planning, Government of the People's Republic of Bangladesh, Dhaka, Bangladesh. p145.

Chen $\mathbf{Y}$ and Dribnenki P (2002) Effect of genotype and medium composition on flax Linum usitatissimum L. anther culture. Plant Cell Rep. 21: 204-207.

Collonier C, Fock I, Kashyap V, Rotino GL, Daunay MC, Lian Y, Mariska IK, Rajam MV, Servaes A, Ducreux G and Sihachakr D (2001) Applications of biotechnology in eggplant. Plant Cell Tiss. Organ Cult. 65: 91-107.

Duncan DB (1955) Multiple range and multiple F test. Biometrics 11: 1-42.

Durzan DJ and Durzan PE (1991) Future technologies: model reference control system for the scale of embryogenesis and polyembryogenesis in cell suspension cultures. In : Deberg, P.C. and Zimmerman, R. H. (Eds) Micropropagation. Klwer Academic Publ., Dordrecht. pp. 389-423.

Gleddie S, Keller W and Setterfield G (1983) Somatic embryogenesis and plant regeneration from leaf explants and cell suspensions of Solanum melongena. Can. J. Bot. 61: 656-666.

Hansen LN, Ortiz R and Andersen SB (1999) Genetic analysis of protoplast regeneration ability in Brassica oleracea. Plant Cell Tiss. Organ Cult. 58: 127-132.

Kantharajah AS and Golegaonkar PG (2004) Somatic embryogenesis in eggplant. Scientia Horticulturae 99: 107-117.

Matsuoka H and Hinata K (1979) NAA-induced organogenesis and embryogenesis in hypocotyl callus of Solanum melongena L. J. Expt. Bot. 30: 363-370. 
Muktadir MA (2008) Development of an efficient plant regeneration protocol for eggplant. MS thesis, Department of Genetics and Plant Breeding, Bangabandhu Sheikh Mujibur Rahman Agricultural University, Bangladesh.

Parrot WA, Merkle SA and Williams EG (1991) Somatic embryogenesis: Potential for use in propagation and gene transfer system. In: Murray, D.R. (Eds.)

Sharma P and Rajam MV (1995a) Genotype, explant and position effects on organogenesis and somatic embryogenesis in eggplant (Solanum melongena L.). J. Expt. Bot. 46(1): 135-141.

Sharma P and Rajam MV (1995b) Spatial and temporal changes in endogenous polyamine levels associated with somatic embryogenesis from different hypocotyl segments of eggplant (Solanum melongena L.). J. Plant Physiol. 146: 658-664.

Steward FC, Mapes MO and Smith J (1958) Growth and organized development of cultured cells. I. Growth and division of freely suspended cells. Amer. J. Bot. 45: 693703.

Yadav JS and Rajam MV (1997) Spatial distribution of free and conjugated polyamines in leaves of Solanum melongena L. associated with differential morphogenetic capacity: Efficient somatic embryogenesis with putrescence. J. Expt. Bot. 48: 1537-1545. 